\title{
Making a Punjabi language documentary film in New Zealand for Punjabi and non-Punjabi audiences
}

\begin{abstract}
The second author interviewed three Punjabi Sikhs in South Auckland on camera in the Punjabi language, and two Punjabi Muslims in Lahore via an online video call where one participant responded in Punjabi and the other in the Urdu language. Their discussions were edited and subtitled in English for a thirteen minute documentary film screened at a migration research symposium and also released on the internet via Punjabi, Indian, and Pakistani multimedia outlets. Our paper speaks about the process of making a Punjabi language documentary in New Zealand for different audiences of university researchers and Punjabi communities. We also present the uncut interviews and the internet link to the film in Punjabi with English subtitles.
\end{abstract}

Dr Teena Brown Pulu is a senior lecturer in Maori and Indigenous Development at Auckland University of Technology. A Pacific anthropologist, she publishes ethnographies of Tongan migrants in South Auckland and their transnational ties to rural villages in Tonga.

Asim Mukhtar Janjua is researching his $\mathrm{PhD}$ at Auckland University of Technology. His doctoral project produces a documentary film and exegesis on Pakistani and Indian Punjabis in South Auckland and their composite culture and history. 


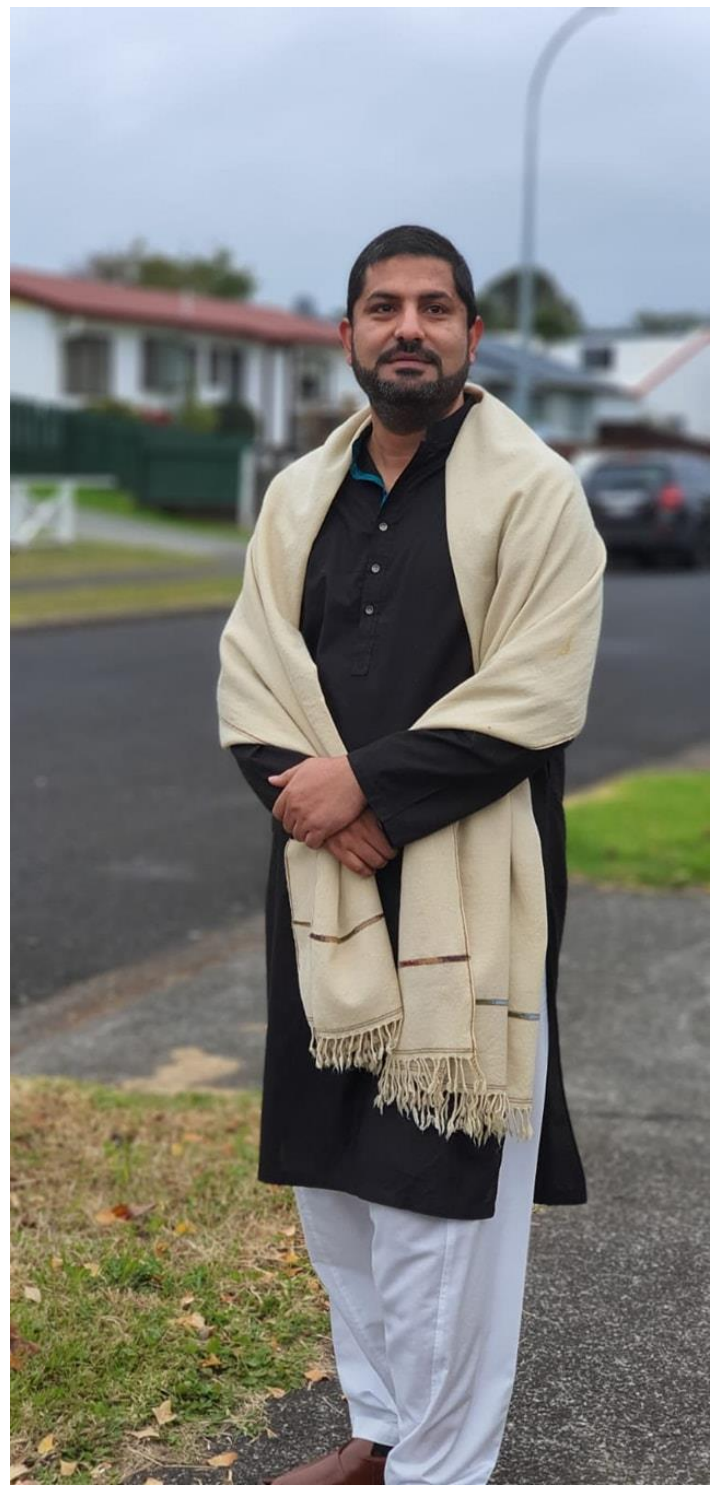

Figure 1: Asim Mukhtar Janjua.

Te Kaharoa, vol. 15, no. 1, 2020, ISSN 1178-6035 


\section{Introduction}

Our writing does not follow an essay formula of beginning with a research question and answering the inquiry by a method of data collection and analysis. Instead, the article talks about making a Punjabi language documentary film in New Zealand and the assemblage of a collaborative documentary for different, quite separate audiences; university researchers located inside New Zealand institutions, and Punjabi communities located throughout New Zealand, Punjab, and the global Punjabi diaspora. Migrants of colour are not merely data, numbers, facts, and statistics in a documentary film when they are speaking personal truths in their mother tongue about lived experiences, feelings, and sensitivities from which they form their social reality.

Therefore, this paper takes a novel trajectory by detailing the second author's process of weaving a filmed collection of stories. This interwoven narrative, we suggest, is capable of reaching diverse audiences with divergent viewer expectations, through a Punjabi language medium and cultural identity anchoring the characters on the screen (Brown Pulu, Mukhtar, and Singh, 2019). Our purpose then, is not to solely focus on the film interview transcripts or the final cut of the film, but rather, to co-construct a reflection piece on film practice when culturally and visually it is pieced together as Punjabi language documentary. The writing strategy is to set the stage for readers who view the film to see and hear multiple Punjabi voices speaking as and for themselves, and to note that the interview transcripts presented in this article were edited and arranged with purpose for the actual film.

The paper is organised in interrelated parts. This first section, the introduction, gives our sense making of the historic context of Punjabi culture and identity moving across borders and boundaries with migrants. The way the documentary was structured is recounted; that is, the process in which the content was created for 
distinct institutional and community audiences at stages of filming and editing. Part two explores the culturespecific aspects of making a documentary in Punjabi with some Urdu by sketching the parameters the filmmaker operates in when producing film as an insider of his ethnic and language community. We also situate Punjabis in a changing ethnoscape (Appadurai, 1996) to contextualise today's world where temporary migration predominates over permanent migration. Part three, the interviews, are the transcripts of filmed talks between the filmmaker and Punjabi participants before the dialogue was edited into smaller pieces to fit the film's form, and lastly in the references, the internet link to the thirteen minute documentary is listed.

\section{Punjabis}

The documentary film, This is what our future looks like: Punjabi views from New Zealand, directed by Asim Mukhtar Janjua, was released to audiences on 4 September 2020. A thirteen minute documentary in Punjabi, subtitled in English, it was screened to university researchers at the Aotearoa Migration Research Network Symposium at 4:00PM on the Friday afternoon, and released at 7:00PM in the evening to Punjabi language communities via the Auckland Punjabi multimedia collective of Kiwi TV, Punjabi Herald, and Radio Spice NZ 88.0 FM. Additionally, several media groups ran the documentary: Apna Television, an Indian entertainment free-view channel in Auckland; The Indian News, an online news outlet in Auckland; and the social media page of Punjabi Lehar in Faisalabad, Pakistan.

Within twenty-four hours of the film's public release, the Radio Spice social media page alone had collected 7,000 views from a Punjabi global audience. This is not to say that individuals from other ethnolinguistic identity groups of the subcontinent (India, Pakistan, and Bangladesh) were not part of the wider South Asian viewership, but more precisely, it highlights that Punjabis made up the principal audience. The plot 
was straightforward: interviews with Punjabis of India and Pakistan about the New Zealand government closing the border on temporary migrants under Covid-19 travel restrictions, and how they saw the future unfolding for their communities (Brown Pulu, 2020).

Appraised by both audiences, academics and Punjabi language speakers, the film served its immediate goal of putting migrant views about the pandemic environment in the broader public domain. The subtle objective of showing cultural resilience in the voices of older, established Punjabis, desiring younger generations to maintain emotional ties to Punjab, and develop a durable cultural identity resistant to assimilation into a dominant language and culture, may have only been apparent to Punjabi audiences for whom that part of the dialogue was directed at. Writing this paper has given us space to contemplate the cultural complexity of interlacing Punjabi stories, and the practice of delivering those stories to Punjabi and non-Punjabi publics. Audience engagement, we think, takes place in multiple ways considering Punjabi speakers and non-Punjabi speakers in the culture of everyday life use their preferred language media to source information about migrant communities of colour, and cultivate their own beliefs about the lives of migrants.

Discourses of Punjabi identity trace their roots and routes to a complicated historic background because even though Indians and Pakistanis are nationals of different South Asian countries with seven decades of strained relations, the second author, Asim Mukhtar Janjua, and the five people he interviewed for the film share the same native language, ethnicity, culture, and history. As an ethno-linguistic group, Punjabis are categorised as the indigenous people of the Punjab, the land of five rivers in Farsi (Persian), but the partition of British India at midnight on August 15th, 1947, divided the region between two states, India and Pakistan, altering the identity of the people and place permanently. 
Severing native land and people along religious lines resulted in "one of the largest ever processes of forced migration" and the "massacres of thousands of lives" (Aiyar, 1995; Dalrymple, 2015). Swarna Aiyar accentuated the major outcome of partition was the direct and significant change of the "demographic profile of the [Punjab] region" (Aiyar, 1995, p. 13). In 1947 then, the sweeping transformation of the Punjab witnessed "four and a half million Sikhs and Hindus moving from West Punjab into the eastern areas that became part of India and an estimated five and a half million Muslims moving in the opposite direction" (Aiyar, 1995, pp. 13-14).

Kamaljit Bhasin-Malik penned that post-partition Punjabi writers in fiction and non-fiction literature have mourned the demise of syncretic "cultural traditions and patterns of co-existence" (Bhasin-Malik, 2007, p. 3). A militarised international border segregating the Punjabis into religious groupings of Muslims in Pakistan, and Sikhs and Hindus in India, not only changed the population characteristics of Punjab, but fractured the composite culture and identity of Punjabis commonly termed Punjabiyat.

'This loss of shared cultural traditions and patterns of co-existence is lamented in much of the writing on Partition, both fiction and nonfiction, and there are frequent articulations of the need to 'preserve a memory, however fugitive, of that culture before time and history have placed it beyond reach.'

Modern day Punjabis have therefore been deterritorialised for seventy-three years, and now refer to the original landmass of Punjab as east Punjab and west Punjab, or the two Punjabs (Ayres, 2005). Although pieces of this territory have been amalgamated into sovereign countries as provinces or states, the Punjab is no longer a self-governing nation in the sense that it was during the era of the Khalsa state from 1799 to 1849 
under the Sikh leader, Ranjit Singh, the Maharaja of Lahore (Grewal, 2008).

One recurring theme when reflecting on the practice of documentary film in the Punjabi language is that Punjabiyat or Punjabiness is heterogeneous, and varies according to a community's location and conditions of existence (Bourdieu, 2000). Shifting places, whether that be by internal or cross-border movement, produces new living circumstances where people of a common language and cultural identity modify their 'habitus' (Bourdieu, 1990); a term Pierre Bourdieu used to describe the ways by which social structures reproduce social practices (Power, 1999).

In the global diaspora, Punjabis since the 1947 partition have traditionally migrated to and created large settlements in northern hemisphere cities of the United Kingdom, the United States, and Canada. Punjabi emigration from villages in east Punjab, India, has been extensively documented, and Steve Taylor noted that "[a]11 existing studies of the global Eastern Punjabi village diaspora emphasise the strength of continuing links between this group, which includes those born and raised away from India, and the rural people and places of Indian Punjab, particularly through kinship ties" (Taylor, 2013, p. 194). Teena Brown Pulu, the first author, has argued elsewhere that the larger share of Punjabi migrants in South Auckland are east Punjabi Sikhs "from mainly rural districts - Jalandhar, Amritsar, and Ludhiana," and that as an identity group "their connectedness to their country of origin, and knowing and talking about what is going on back home regarding Punjabi politics and society" symbolises their collective cultural strength (Brown Pulu, Singh, and Sarkaria, 2018, p. 130).

An estimated fifty thousand Punjabi language speakers live in New Zealand in which forty thousand are Sikhs of east Punjab, India. A smaller percentage are Muslims of west Punjab, Pakistan, and a marginal share are east Punjabi Hindus. However, demographic profiles 
of east Punjabis and west Punjabis are akin by measure of both groups comprising of mainly permanent residents or temporary visa holders, and some New Zealand citizens. The vast majority of the Punjabi population are migrants, and 2014 to 2019 saw the largest totals of Punjabis entering New Zealand and settling for the most part in South Auckland. In these five years the Punjabi migrant category constituted a sizeable skilled professional class of university graduates in communications technology, science, and business, as well as international students. It was a period that witnessed some Punjabis successfully obtain New Zealand permanent residency or citizenship. But even more pressing was this time in Punjabi migration history incubated a social expectation where it was thought temporary movement for professional employment or postgraduate study would lead to permanent residency.

\section{Documentary Film}

The documentary's ethnographic content was based on three individual Punjabi language interviews, plus an extra interview given by a married couple in Punjabi and Urdu languages. The four transcripts, translated into English, appear at the end of this paper in the order of which the Punjabi participants were interviewed, and not in the order in which they appear in the film. A culture-specific way of framing the interview group is to say that the dialogues recorded on camera represented the Punjabi views of three Sikhs of east Punjab, the Indian side of Punjab, who spoke Punjabi, and two Muslims (a married couple) of west Punjab, the Pakistani side of Punjab, where the husband communicated in Punjabi and the wife responded in Urdu. A generalisation not accounting for the cultural identity of participants would be to classify this interview group as two migrants from India, two migrants from Pakistan, and one New Zealand born Indian.

Describing the field sites in Auckland, East Punjabis were interviewed separately at three locations in 
various suburbs; the public library in Grey Lynn, Radio Spice NZ 88.0 FM in Papatoetoe, and the town centre and Gurudwara Nanaksar (Sikh place of worship) in Manurewa. The west Punjabi husband and wife were, from March 19th 2020, excluded from entering New Zealand as temporary visa holders due to Covid-19 border controls. Stranded with their children in their home city of Lahore in Pakistan, they talked with Asim in an online video call cut-short due to the poor internet connection at their end.

Interview questions put to the Punjabi Sikhs revolved around the future for Punjabi language communities in New Zealand amid the pandemic environment of closed borders and suspensions on temporary visas for work, study, and travel. Two of the Sikhs had been visiting their families in east Punjab when India's lockdown came into effect on March 25th, 2020, and spoke of anxiety in waiting four months for repatriation flights for New Zealand citizens and permanent residents. Their impressions offered rich, first-hand observations, which we particularise later, but in spite of this, it was cut out of the documentary because the plight of temporary migrants outweighed other details. Interview questions put to the Punjabi Muslims were adjusted to their situation of being brought to a double halt by the Punjab province lockdown in Pakistan on March 24th, 2020, and the impenetrable New Zealand border. They were asked about their personal predicament and how they saw their family's future.

Close to four hours of raw footage was recorded with longer discussions given by the Punjabi Sikhs. After cutting down two-hundred and forty minutes to sixteen, the film was reworked with the interview dialogues being condensed even further. The internet link to the documentary posted on a YouTube channel is cited in this paper's references section, and we ask readers to view the film to absorb the editing method of selecting snippets of speech from raw footage to craft a narrative. 
This narrative was fashioned for two specific and separate audiences who made collective sense of the characters and stories differently. The difference was fixed to the language in which they had decoded the screenplay and created meaning from the text, image, and sound (Hall, 2006). University researchers were the audience reading the English subtitles for information on the subject of migrants in the Covid-19 pandemic environment. Punjabis were the audience listening to the spoken Punjabi and Urdu, grasping nuances and hidden meanings in the languages, and watching for social cues in characters' gestures and facial expressions, the narrator's voiceover, Punjabi music genres, scenery changes, and the visual aesthetic and artistry.

Distinct to regular cinema goers of foreign language films who find "that watching a subtitled film in the cinema helps them learn a language or improve their knowledge of a language" (Widler, 2004, p. 99; O'Sullivan, 2007), non-Punjabi researchers were not viewing the film to learn Punjabi for gaining a deeper understanding of cultural identity. It could be argued that this particular audience was surveying the screen for data to support their research orientations in migration studies.

The transcripts included in this paper are taken from the sixteen minute rough cut of film, signalling to the second stage of offline editing in Asim's postproduction process of digital filmmaking. The third stage of offline editing involved shortening the rough cut of interview dialogue and adding English subtitles, allowing for less than a minute to insert voiceover narrations by Asim and non-narrative breaks. Captioned on the screen were bare translations of Punjabi into English. We mean to say the English interpretation of Punjabi had to fit words squarely on the screen and allow the non-Punjabi audience adequate time to read the text. By doing so, the metaphor, nuance, and emotion of the vernacular faded in the subtitles. Supplementary footage produced mainly by Punjabi videographers was set in the background of the interviews to visualise, and furnish the film with an 
aesthetic feel of, the two Punjabs and Punjabis in Auckland alongside various Punjabi music styles by artists in India and Pakistan.

The concluding stage of post-production before screening the film to researchers and releasing the documentary to the public on internet platforms was circulating the final cut to interviewees and Asim's network of filmmakers for reviews. Punjabi film producers suggested small edits, which were weighed up against the pitch to different audiences; that is, figuring out how to situate the cultural value of Punjabi storytelling sewn onto an intricate social tapestry close enough to reach an academic audience. The non-Punjabi audience had anticipated a complete and linear narrative evident in the English subtitles and arranged in a seminar presentation. The Punjabis were awaiting the internet release of a documentary snapshot of migrant life in New Zealand that they could relate to, and see themselves reflected in, through the characters and their stories.

\section{Discussion}

\section{Punjabi Language Documentary}

Amateur producers in the twenty-first century have mobilised the masses around a global Punjabi identity by making community and culture-centred digital film in the Punjabi language, mostly without English subtitles (Roy, 2007, 2010). Elizabeth Coffman argued the affordability of digital cameras, film equipment, and internet access in developed and developing countries has cultivated the abundance of community storytelling through collaborative documentary filmmaking (Coffman, 2009, p. 62).

Contrary to fears that the age of cinema is ending, this new age of digital media offers more, not fewer, opportunities for individuals or groups interested in producing documentary work. Documentary opportunities exist beyond 
the feature film industry and its traditional, author-centered documentary genre.

Altering from author-centred to collaborative documentary is a complex transition for filmmakers in Asim's in between position who produce culture-centred film for fellow native language speakers as the primary audience, and for university researchers to read English subtitles of their visual work (Sarroub, 2002). More often, it is the university audience who expect to see an authorcentred film and text from being located inside research institutions where sole-authorship is the dominant practice.

The one-day meeting of migration researchers at the Aotearoa Migration Research Network Symposium was hosted by the University of Waikato with a limited number of in-person attendants determined by New Zealand pandemic restrictions on the size of group gatherings. Asim screened the documentary from his home in South Auckland via Zoom video conferencing, and in many ways the conference agenda had dictated the structure and content of the film. The call for papers written by the organisers laid down what could, and could not, be said about the subject (Foucault, 1971) by the way in which presenters were instructed to address the central theme, the main idea, framing the proceedings: Migration in uncertain times: $\mathrm{Im} /$ mobilities, belonging and identities in Aotearoa/New Zealand. The final cut of the documentary film was constructed by picking conversation pieces out from the rough cut that gave emphasis to vocabularies contained in the symposium brief: migration, mobility, and Punjabi identity.

Outside the confines of the seminar/webinar, the collaborative process of making a Punjabi language film dictated social exchanges between the researcher and research subject of Punjabis of India and Pakistan living in New Zealand. The language spoken in the interviews defined and confined the cultural meanings of migration and mobility, and in turn, these co-constructed 
understandings shaped how Punjabi identity was experienced and made collective sense of during exchanges between the Punjabi who asked questions and the Punjabis who responded. Underlying their mutual conception of mobility was the social reality that five million Punjabis have migrated from east Punjab and west Punjab to metropolitan areas in primarily northern states. Recent flows of Punjabis into New Zealand are therefore perceived as corresponding with global international movements, and not interpreted as a Punjabi population cluster growing in the southern hemisphere that is unrelated to, and isolated from, larger Punjabi settlements in Australian and northern hemisphere cities.

Unintentionally, part of the film composition ended up spoken in two languages, Punjabi and Urdu, which are not interchangeable. Not all Punjabi speakers understand the Urdu language and not all Urdu speakers, despite identifying as Punjabi by ethnicity and culture, are capable of communicating proficiently in spoken Punjabi (Khokhlova, 2014). Urdu, the national language of Pakistan, is employed as the official mode of communication by the federal government, parliament, state bureaucracy, armed forces, education system, and media. By contrast, the state of Punjab in India is the only place in the world where Punjabi is the official language.

To explain, in west Punjab, Punjabi is the language of "the home domain" (Kaur, 2019) and Urdu is the language of the state. Gwendolyn Kirk noted, "Punjabi is the mother tongue of about 45 percent of the Pakistani population and the most widely-spoken language in the most politically and economically powerful province" (Kirk, 2016, p. ix). Kirk expanded on the film industry flipside where "Punjabi films, like the language, are heavily denigrated by the cultural elites (particularly the English-speaking upper class) as crude and vulgar" (Kirk, 2016, p. ix). Therein lies one complexity of Punjabi cultural identity in an express location. Urdu is the "mother tongue of only $7.57 \%$ of the people" (Rahman, 
2006, p. 73) but is driven by nationalist sentiments to be "a symbol of unity [in] helping to create a unified "Pakistani" identity" (Rahman, 2006, p. 74). Tariq Rahman affirmed that the national language, Urdu, "serves the political purpose of resisting any ethnicity which could otherwise break the federation" (Rahman, 2006, p. 74).

Generally for Punjabi audiences, when people detect the film dialogue shifting from Punjabi to Urdu, it triggers the social imagination to picture different locations, territories, and nations. Like crossing the Wagah-Attari international border by foot, the place on the map "where the nation-states of India and Pakistan begin and end" (Navtej Purewal cited in Parciack, 2018, p. 746), the camera and language alters from Sikhs of east Punjab to Muslims of west Punjab. At a deeper level of consciousness, the film shots and voices move around Punjabi Sikhs in South Auckland showing characters who have maintained close connections to their kin and kith in east Punjab, India. Importantly they have obtained the security of permanent residency or citizenship in New Zealand. Mixed into this narrative was a smaller story introduced early on in the piece at 3:08 minutes when Asim's voiceover gestured to shots of the gated city of Lahore and the Pakistan flag at 3:16 minutes, which leads viewers to a Zoom video meeting at 3:18 minutes. Here, the audience looks at a west Punjabi Muslim couple on a computer screen who are Pakistani citizens and temporary migrants being kept out of New Zealand (Brody, 2015).

\section{Research as Relationship}

The interviews in South Auckland were planned and talked through before filming took place between Asim and the east Punjabi Sikh participants, Gurmeet, Harjeet, and Ajit. Asim hand-picked characters with whom he had existing community relationships, and was guided by the logic of "research as relationship" (Ceglowski, 2000). Sustaining relationships in the field 
throughout the course of pre-filming, production, and post-production, determines the quality of collaborative documentary work. Gathering participants who were at ease to converse with him on and off camera was important, but they were also people known to Punjabis in South Auckland and whose stories would help generate internet viewership.

While visiting east Punjab in late March, Gurmeet and Ajit were held there under India's lockdown, which the federal government made compulsory for twenty-nine states and seven union territories. Both of these characters had direct memory of scrambling for limited repatriation flights for New Zealand citizens and permanent residents. The New Zealand government arranged three chartered Air New Zealand flights from New Delhi to Auckland between April and July 2020, prioritising New Zealand citizens, for more than twothousand eight-hundred passengers (New Zealand Government, 2020). India's federal government, by comparison, authorised nine Air India flights for the same period from New Delhi to Auckland to bring back Indian citizens on visitors' visas to New Zealand (India Government, 2020). Most Punjabis with New Zealand citizenship or permanent residency returned to Auckland on Air India flights from mid-June to July after finding out they were not included on the Air New Zealand priority list. Harjeet, Asim's co-broadcaster for their weekly show Sanjha Punjab which is live streamed on the internet for Radio Spice 88.0 FM, had played a journalism role of communicating with Punjabis on temporary work and study visas who had been prohibited from reentering New Zealand.

Visual ethnographer Harjant Gill spelled out in his paper, Before Picking Up the Camera: My Process to Ethnographic Film, the pre-interviews, meaning the social exchanges of the interviewer and interviewees in advance of the actual videoing, is the vital ingredient in documentary film practice (Gill, 2014, p. 72). Adapting aspects of Gill's method, Asim first drafted a screenplay 
conceptualising interwoven Punjabi stories. He then edited the script and interview schedule after the preinterviews by reconfiguring how the film, in practical terms, would work for each character in respect to interview location, camera shots, and supplementary footage inserted to underline viewpoints that were likely to make the final cut. Putting questions to people placed in front of the camera employs a fieldwork method dissimilar to audio recording participants for publishing excerpts of their interviews in a research paper. The film director and camera operator can shoot and reshoot parts or all of the interview until thoughts and words flow lucidly.

With that said, interviewing the married couple stranded in Pakistan had not been written into the original screenplay, and the exchange was recorded once through an online video platform. These were west Punjabi Muslims whom Asim had not met in New Zealand or Pakistan and did not know personally. As well, they were based in Christchurch, a city placed outside of his closest Punjabi Pakistani community networks in South Auckland. Asad Anwar and Somia Tasneem were a husband and wife anxiously waiting for the New Zealand border to reopen for migrant families with temporary visas desperate to return to their homes, jobs, schools, and lives. From within Asim's set of contacts, he had learned that Asad, Somia, and their school age children had been immobilised by closed borders during a visit to Somia's family in Lahore. Despite having completed the rough cut and English translations (for subtitles) of three planned interviews in South Auckland, he contacted Asad with a mind to include a discussion, a filmmaking decision which entailed rejigging the original script.

Reorganising the screenplay to bring in a conversation where Asad had responded to Asim's questions in Punjabi and Somia in Urdu, and then position their views next to Gurmeet, Harjeet, and Ajit who had talked in Punjabi - two languages, two locations, one cultural identity - meant adjusting some of the focus. 
The urgency with which temporary visa holders search for border openings in the transience of their lives was highlighted at the mid-point of the film. Leading into the second excerpt of Asad and Somia telling their personal story was a momentary omission from Ajit at $7: 11$ minutes who featured before them: "On a humanitarian basis, those people must be allowed to come back, and I think as a community we should lobby for that."

Ajit was signalling to east Punjabi temporary migrants caught in between India's lockdown and New Zealand's closed border. Calling for the community to press their people's case to the New Zealand state did not mean advocating exclusively for Punjabi Indians. To the contrary: in South Auckland where most Punjabis have established themselves, the Punjabi community is not a signpost pointing only to east Punjabi Sikhs. More accurately, this identity marker accounts for the Punjabi language communities of the two Punjabs. Gurpreet Kaur remarked in her study of how Sikh Gurdwaras (places of worship) in the Auckland region have sustained Punjabi language and cultural identity that: "[T]he Panjabi language which is taught in community schools is not a signifier of Sikh religion but of Panjabi culture" (Kaur, 2019, p. 30).

The reason for Asim depositing Punjabi language documentary film on free access internet platforms of YouTube, Facebook, and WhatsApp was to reach the Punjabi public, a large global audience compared to the small number of New Zealand based researchers of migration studies who are social scientists and policy analysts, not filmmakers. Punjabis worldwide exhibit cultural preferences for viewing material couched in their collective identities and issues, and documented in visual and aural media that is aesthetically pleasing by their tastes and canons. Film is made to be shared publicly, and cultural film is distinctive to other documentary genres because it is crafted for a niche audience to whom the culture and language, the very subject of the film, belong. 
Harjant Gill's sentiments convey a cultural truth: "Ethnographic filmmakers often have to find audiences by being their own cheerleaders and communicating why their films matter" (Gill, 2014, p. 73). It is here that we must explain the cultural politics that underlie Asim's activism in documenting film in his native language of Punjabi, a language which has been historically subjugated as inferior to Urdu and English in his country of origin, Pakistan, since the colonial epoch of British India. Screening Punjabi language film to both audiences, migration studies researchers and Punjabi language communities across the globe, is a highly political act for different reasons depending on the audience.

One such challenge lies in convincing certain researchers that documentary film made by migrants in their mother tongue is reliable research systematically organised by processes of collaborative inquiry and sensemaking. Empiricists believe their investigation methods have superior rigour, and often foreign language film is relegated outside the confines of accuracy to anecdotes. An even more arduous task is proving to some Punjabis that prioritising Punjabi language as the fundamental medium in documentary film made about Punjabi cultural identity, by no means destabilises their religious identity, or national patriotism.

When reflecting on how Punjabi language documentary film becomes a cultural location of characters, lived experiences, and cross-border connections and tensions, the observation of Deborah Ceglowski is evoked (Ceglowski, 2000, p. 98).

Typically, our research texts discuss research procedures, not process, and they describe the research site, not the complexity of our relationships.

Asim's insider position prompted him to allow the research process to evolve at various stages of preinterviews, production, and post-production for the 
simple reason that the project was a collaborative work, and consultations with characters and producers ensured a way to draw on their assessments for decisions about creating and editing a film. However, this very method revealed that the relationship between the researcher and the subject being researched was sculpted by intersecting factors: the language in which each interview was carried out, Punjabi primarily, with some Urdu, and the identity formations constructed around the significance of speaking and sustaining the mother tongue for migrants.

\section{Situating Punjabi views}

For Punjabis when they envision the global ethnoscape (Appadurai, 1996), it entails picturing the circular movement of five million Punjabi migrants living outside of India and Pakistan. The living landscape of Punjabi international migration is deep-rooted in a system of emigrating from east Punjab and west Punjab into a diaspora spanning metropolitan centres from the northern to the southern hemispheres. Outward movement is also coupled with return movements of migrants regularly visiting their places of origin. Steve Taylor and his co-authors used sociological theory to structure Punjabi transnationalism by interpreting international migration and return international movements as a pathway to social class and status (Taylor et al, 2007, p. 329).

Eastern Punjabi transnationalism supports those [researchers] who contend that access to international migration is becoming an increasingly significant component of contemporary global social stratification.

Asserted here is the argument that the economic earning power of Punjabis living overseas, in contrast to their villages and districts in east Punjab, India, has entrenched social inequalities between homeland and 
diaspora populations. It is the kind of structural analysis that contends international migration reinforces a global economy dependent on migrant workforces, while at the same time, weakens the local economies of developing countries based on crop growing and pastoralism. But it also contains a rationale that can partly explain why migrants of the professional class who are stopped, without warning, from moving through borders would pressure governments on humanitarian grounds for the right to migrate for work and upward mobility.

The social behaviour of Punjabis shifting places for employment and education has a post-independence history of seven decades, which reached a pinnacle in the last two decades. In our present times, temporary migration outweighs permanent settlement, and highly skilled migrants from the subcontinent have acquired degree level education in their countries of birth with a sense of entitlement to migrate and secure specialist careers in western developed states.

Beyond the limits of this paper is the question of how much the preservation of Punjabi language and culture plays into people's decisions to migrate with a mind to work to obtain permanent residency in New Zealand, eight-thousand miles away from the two Punjabs. Gurmeet and Ajit responded somewhat to this query in their filmed interview excerpts when it was put to them: will Punjabis raised in New Zealand continue to hold on to Punjabi language, culture, and identity?

Parents "want their children to be devoted to their heritage," exclaimed Gurmeet. Likewise, Ajit affirmed that Punjabi parents "must take their children to Punjab at a young age as this helps children to develop a long lasting relationship with their culture." In many ways, travelling back and forth from New Zealand to Punjab serves a dual purpose of maintaining the flows of temporary migrants as well as generations of migrants and overseas-born children keeping up their cultural and language connections to an ancestral homeland and people. 
We end this paper on same tone that Marcus Thompson wrote in when publishing his fieldwork notes in 1974. Thompson had interviewed east Punjabis migrants who settled in the United Kingdom after the conclusion of World War II and the 1947 partition of British India into the independent states of India and Pakistan. He wondered about the "second generation" of young Punjabis born and raised in the United Kingdom: would they speak Punjabi or English, and were they concerned about holding on to "their Punjabi identity" when they were British citizens? (Thompson, 1974, p. 242).

The majority of the second generation do not want to give up their Punjabi identity and wholly to adopt English norms of behaviour; instead they want to liberalise the traditional village and family regime of Punjab.

The documentary film interviews in This is what our future looks like: Punjabi views from New Zealand have prioritised the voices of migrant working parents Harjeet, Asad, and Somia, which were arranged next to Punjabi community elders - Gurmeet and Ajit. However, there were signposts of what this interview group might want the future to look like for Punjabi language communities established in New Zealand. Punjabi "parents have a strong desire for their children to be committed to Punjabi culture and love for their motherland," avowed Gurmeet. In saying that, producing a documentary film of putting questions to New Zealand born Punjabis on maintaining language and culture would make a follow-up project, which not only focuses the camera on the second generation, but enables young Punjabis to speak of their identity in their own words. 


\section{Interviews}

\section{Gurmeet Singh Sarkaria}

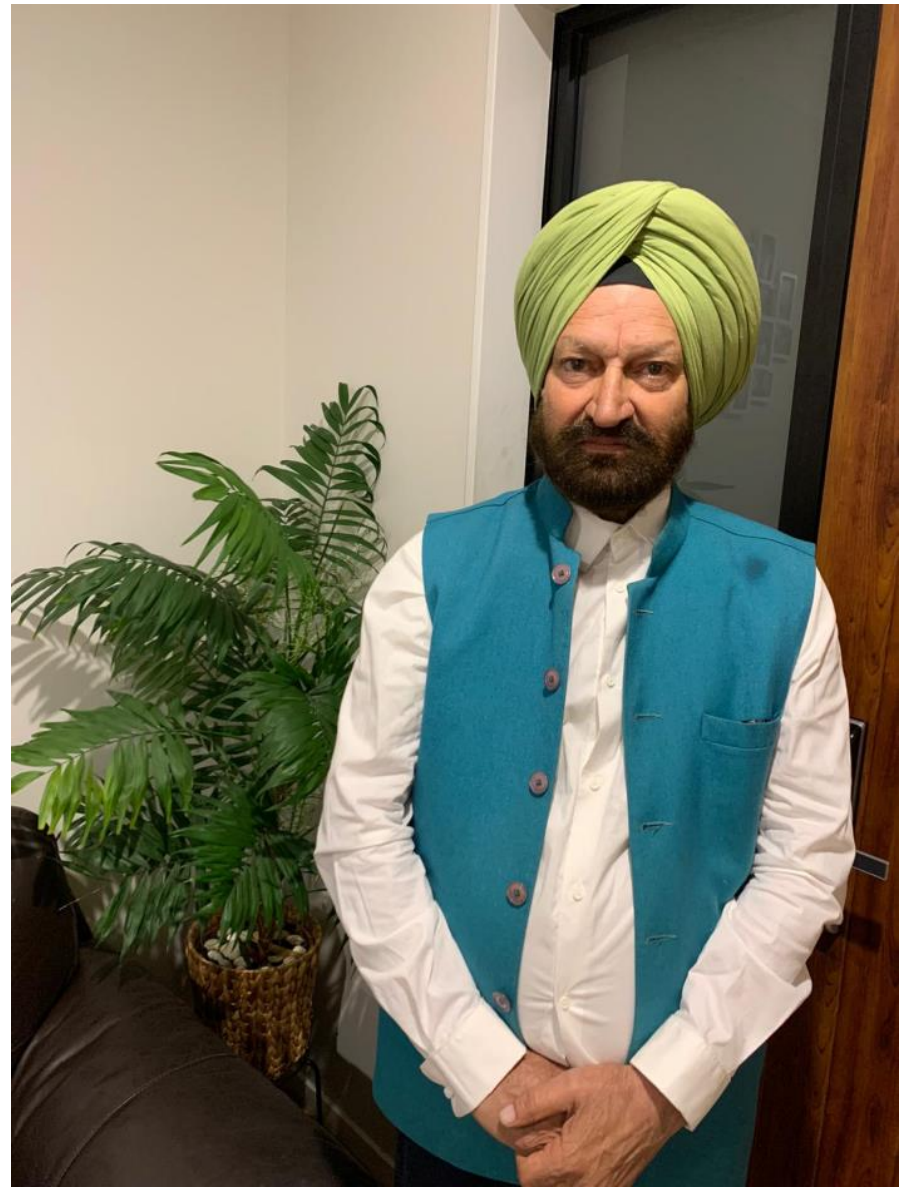

Figure 2: Gurmeet Singh Sarkaria.

Asim: What was it like being stuck in Jethuwal under Covid-19 lockdown, and how were people in the rural districts coping? 
Gurmeet: Lockdown commenced on the 23rd of March and precautionary measures came into force immediately. The emphasis was more on travellers who came from overseas. For this purpose, the state did a house-to-house survey asking important questions about whether people had Covid-19 symptoms, such as the flu, sneezing, or coughing. Covid-19 testing was conducted on people who had symptoms. The Punjab police was also actively involved in the Covid-19 response of door-to-door surveying.

Asim: What are the people of east Punjab saying about the future of their state, and what are the main concerns for them?

Gurmeet: There was a general state of fear, and to some extent, panic among the people. This pandemic came out of nowhere, and all of a sudden it was proving to be a life threatening and dangerous virus. The news updates on Italy, America, and England showed the devastating impacts of the global pandemic, which stirred fear in the minds of people. Some even started making masks at home and wearing them all the time. Others stopped engaging in group activities, and closed down their businesses and shops as the self-prevention measure.

Asim: Were there many overseas Punjabis caught in the same situation as you, and how hard was it to get a flight back to Auckland from east Punjab?

Gurmeet: There were people in our village that came from Dubai and Singapore. From New Zealand, my close family and relatives, including my brother-in-law and my cousin's family of a husband, wife, and three children, all went to India and got stuck due to travel restrictions. In April, we started receiving messages from the New Zealand government that repatriation flights were about to commence. Travel was based on a priority basis, and we were provided with a list of names. New Zealand citizens were the top priority, and then came the elderly, and citizens and permanent residents with family. Details about the status of temporary visa holders were to be announced later. However by the 23rd of April, all flight 
schedules to New Zealand were suspended. This situation put us in a state of desperation as to what will become of us as the future of our travel became uncertain.

Asim: What does our future look like for Punjabis in New Zealand in this environment of closed borders and restrictions on travel and work visas?

Gurmeet: Just like the authorities of New Zealand made efforts to bring back their citizens and permanent residents, Punjabis remain hopeful that temporary visa categories, such as work permit holders, international students, and others, will be treated the same. It is our genuine desire that similar efforts should be made for them.

Asim: Will Punjabis continue to migrate to New Zealand, and do you think you'll be able to travel back to New Zealand for your annual visit in 2021?

Gurmeet: The pandemic is global and not restricted to India and New Zealand alone. This is an issue for every Punjabi across the globe. People from Punjab are not restricted to migrating to New Zealand. Some Punjabis have to go to Canada, America, England, Australia and other countries. It is an instinct of us Punjabis to migrate, and we are fearless in the face of such difficulties. Our people will keep up their efforts to go back to New Zealand and other countries.

Asim: Will Punjabis raised in New Zealand continue to hold on to our culture, language, and identity?

Gurmeet: In such cases, parents have a strong desire for their children to be committed to maintaining Punjabi culture, traditions, language, and love for their motherland. They want children to be devoted to their heritage. The Supreme Sikh Society [of New Zealand at Gurdwara Sri Kalgidhar Sahib Takanini and Gurdwara Sri Guru Nanak Dev Ji Otahuhu] has a major role to play in this community work. Parents take guidance from them on heritage programmes for children. Supreme Sikh Society conducts a range of forums where the children participate, and is taking a lead role in keeping the virtues of our culture alive. 


\section{Harjeet Kaur}

Asim: Tell me the stories you have learned of temporary workers and international students stuck in east Punjab who are unable to enter the New Zealand border due to the Covid-19 restrictions on immigration?

Harjeet: We [at Radio Spice 88.0 FM] have learned about many stranded migrants through social media. I know of three to four families stranded in India. They went for vacations to visit their families, and have found it very difficult under lockdown with sudden travel restrictions, especially for workers on temporary visas. It is heart breaking listening to their stories about the hardships they are facing. The uncertainty of the future makes them feel like the whole world is caving in on them. They have no information on when the international border will be reopened for them to return to New Zealand. Also, it is unclear whether they will be able to hold on to their jobs, or how long employers will keep their jobs for them. 


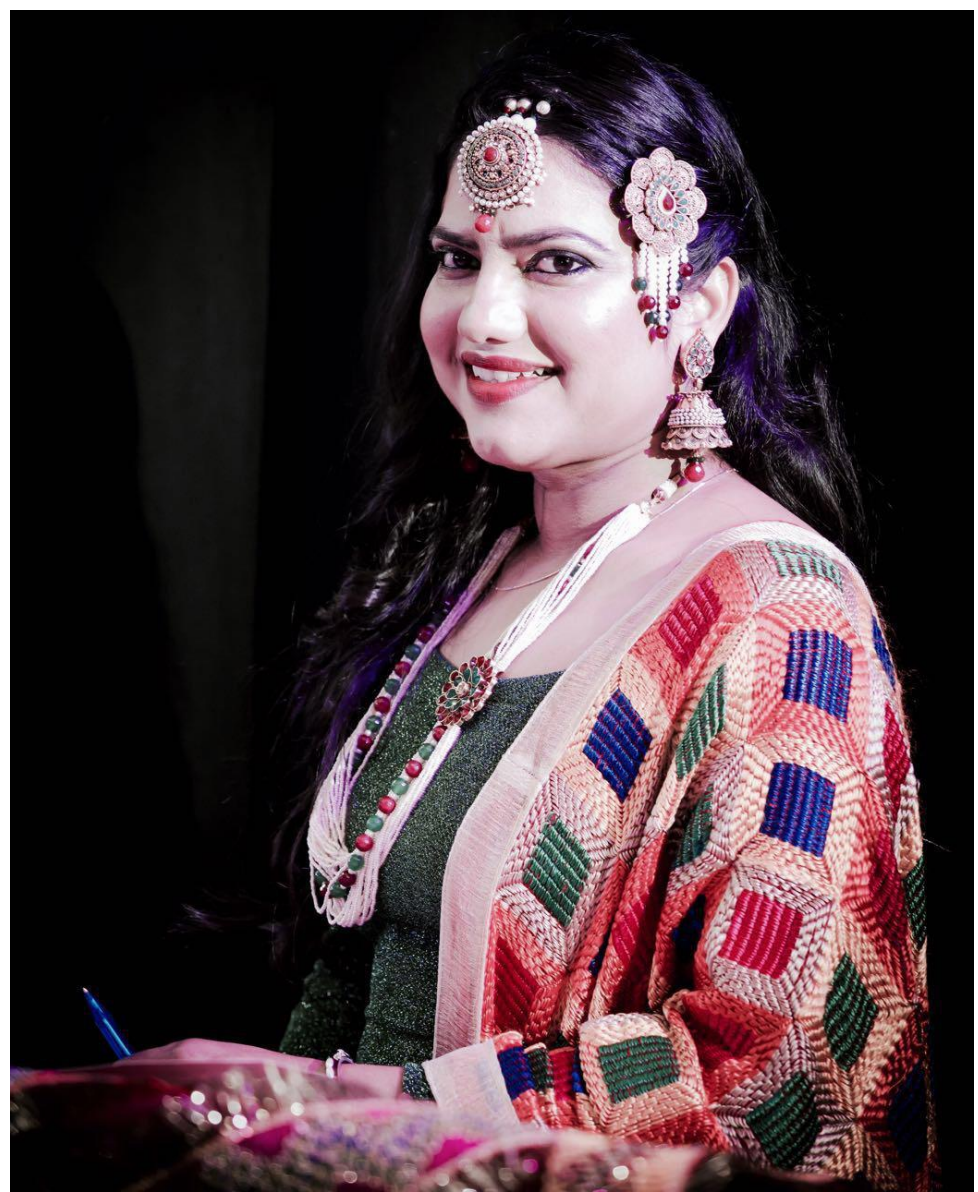

Figure 3: Harjeet Kaur.

Asim: How has this affected Punjabis in South Auckland, knowing that there are people back home that cannot get through the border for work or study?

Harjeet: Not only in Auckland; if we are talking about Punjabis then a lot of people have immigrated to different countries worldwide. If we are talking specifically about South Auckland, which is considered the hub of Punjabis 
in New Zealand, then there were some instances where people stranded in Punjab were employed by business owners. In telling the stories of temporary visa holders and their unfortunate situation of losing jobs, we also need to see the predicament of employers faced with the difficult decision. They can either provide job security to their employees stranded overseas, or save their businesses by recruiting new workers who are able to work.

We are regularly in contact with stranded migrants through social media exchanges, enabling us to develop strong bonds by listening to and reading about their hardships online. Although we are safe here in New Zealand, the situation back home is worsening by the day which worries them, and in saying that, we are equally worried for them. They have dreams, similar to us, to settle down in New Zealand and build a better future. Every migrant leaves their country behind with dreams, and we can feel their pain.

Asim: What does our future look like for Punjabis in New Zealand in this environment of closed borders and restrictions on travel and work visas?

Harjeet: It is too early to say. Things will become clearer once the international border is reopened. I am not sure if this will happen any time soon. But considering the current economic situation, the New Zealand government may decide to soften the border soon. I feel it will take a while until the international border is fully reopened in light of the global Covid-19 situation in countries, such as ours, Pakistan and India. New migrants will make plans to move, and stranded temporary visa holders will stay stuck in their situation, stuck in a date palm unable to move. Punjabis remain hopeful. It is hope that makes the struggles of life colourful and builds character.

Asim: Will the new Punjabi generation raised in New Zealand hold on to our culture, language, and identity?

Harjeet: People can consider themselves Punjabi if they speak our Punjabi language. If Punjabis will not speak the Punjabi language then no longer will we be considered 
Punjabis. I believe Punjabis can only retain their culture, tradition, and values by holding onto their language. I am very hopeful that our Punjabi identity will flourish if we keep on speaking Punjabi language at home with our children. Punjabiyat will continue in New Zealand if we encourage our children to speak Punjabi in our homes.

\section{Ajit Singh Randhawa}

Asim: What was it like being stuck in east Punjab under Covid-19 lockdown?

Ajit: Covid-19 virus has shocked the entire world. I met many people who were saying that they have never experienced such a situation in their entire lives. Culturally for Punjabis, it is difficult to maintain social distance with others. When Punjabis meet, we always hug one another. When the government enforced social distancing and stopped mass gatherings that was an odd experience for the people. However, when they started learning through social media of the awful stories about those who were Covid-19 infected, it was then that they realised how dangerous and harmful the virus was. The economy has suffered hugely due to the virus and with the closure of factories and shops, the daily wagers have been the most affected population. It was strange for the underbelly of the economy, which is invisible to the general public and hidden in the slums, to appear on the road [the migrant workers walking back to their states] where every person could see that this was a time of great suffering for all people. 


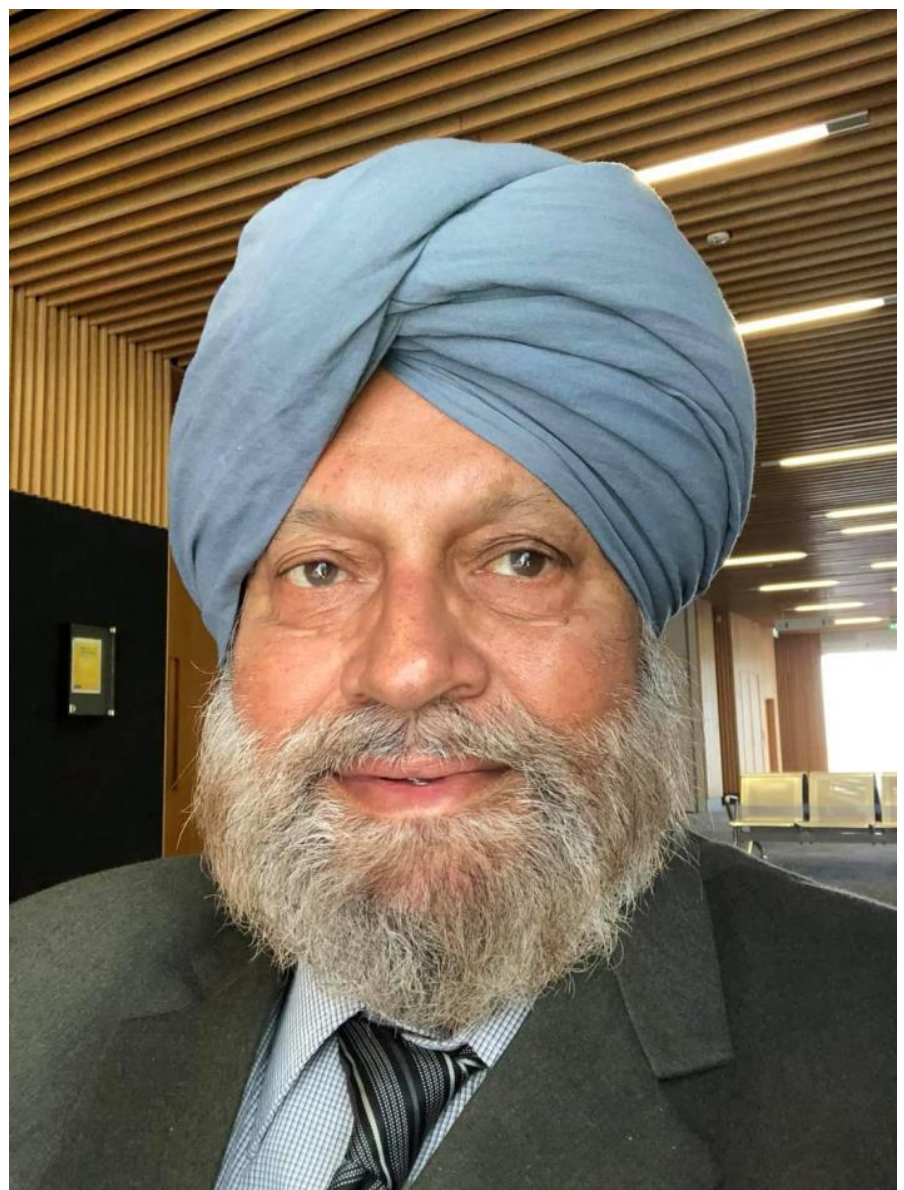

Figure 4: Ajit Singh Randhawa.

Asim: Were there many overseas Punjabis caught in the same situation as you, and how hard was it to get a flight back to Auckland from East Punjab?

Ajit: The flight closures worried us a great deal. I booked a flight back to Auckland for the 18th of March but it got cancelled and I was stranded in Punjab for almost twoand-a-half months. The border closures have affected people visiting their families and tourists the most. It was 
very difficult to secure a seat in the government repatriation flights. Naturally, my family was worried about me as New Zealand is one the safest countries and the virus was on the rise in India. There are still many people stranded in India. On a humanitarian basis, those people must be allowed to come back, and I think as a community we should lobby for that.

Asim: How has Covid19 affected east Punjab, and what are the people saying are the main concerns for their future?

Ajit: It has adversely affected business, industry, and commerce. There was some state support for the farming industry in which farmers were able to harvest wheat and cultivate rice. The government allowed agriculturalists to carry on with their daily routine. But other industries have suffered terribly, and this critical situation is new and real consequences will be felt economically by the end of the year.

Asim: Do you think the government will open the border again, and what does our future look like for Punjabis in New Zealand in this environment of closed borders?

Ajit: Yes, the government will open the border because the demography of New Zealand does indicate there is a need for migrants. When migrants are spoken of, there are illfeelings towards one Asian nation, which I don't want to name here. The viable alternative is India, especially Punjab. The government has to allow migration from the Indian subcontinent, as this is the region that has a young and qualified workforce. The way that the demographic profile of New Zealand is aging, it is inevitable that migration is necessary. Yes, sometimes governments can play political point-scoring and say otherwise. But in the long term, I still see very bright future for Indians and Pakistanis, and especially for Punjabis.

Asim: Will Punjabis raised in New Zealand continue to hold on to our culture, language, and identity?

Ajit: This is the question that comes to my mind. Ultimately the sustainability of anything is a great 
achievement. Punjabis are migrating to other countries and amassing a sizeable population. Our music, culture, and our social norms are going to influence our new generations. According to my personal experience, I would like to suggest to every Punjabi parent that they must take their children to Punjab at a young age as this helps children to develop a long lasting relationship with their culture. Occasionally I visit Queen Street and I do hear Punjabis speaking here and there, which I think is great considering a few decades back we were not welcomed on Queen Street [the main street of Auckland city]. Punjabi is becoming the second most spoken language in New Zealand, and this is the cultural change that has happened over the years. We have flourished in number in the five-to-six Western countries that speak English where we have moved to, which is helping our culture to thrive, and also nurtures us to remain connected with our Punjabi Identity. I am very proud to see young people like you are trying to document our history and culture, and spreading it to wider Punjabi community. As I have noted, our real hope is with your generation.

\section{Asad Anwar and Somia Tasneem}

Asim: What were you doing in New Zealand?

Asad: I used to work as an inventory controller at $P A K ' n S A V E$ [supermarket franchise] in Christchurch.

Somia: I was also doing a $\mathrm{PhD}$ in history at the University of Canterbury.

Asim: How did you get stranded in Lahore?

Somia: We came here to visit our family and within a week of our visit we learnt that the Punjab provincial government in Pakistan was implementing a lockdown. Then we learnt the New Zealand government had also implemented a lockdown. We have been stuck in Lahore since then.

Asim: What was it like being stuck in Lahore under the Covid-19 lockdown? 
Asad: The children have been very unsettled during the lockdown. They just don't know what to do with themselves and how to cope being cooped up. The children are of two minds and feel confused because of the different school curriculum in Pakistan compared to New Zealand.

Somia: Because of this confusion, they have been unable to continue with their schooling here. Under these circumstances, it is not clear what the future holds for us and we are not sure what might eventuate. The level of uncertainty is high, and we simply cannot forecast what will happen from one day to the next. Since March when we arrived in Pakistan, we have been living in limbo and feeling unsure about the future.



Figure 5: Asad Anwar and Somia Tasneem. 
Asim: What dreams and future plans did you have for you and your family?

Asad: We had planned to have a bright future in New Zealand, which all seems now like it has been crushed. We wanted the kids to have a good education and I had hoped to secure a good job to support my family. Luckily I was able to secure work before travelling to Pakistan. Everything seemed to be going well. We had good community support, good people around us, and a good living environment. Everything was working for us, so we started dreaming about a better future for our family. This pandemic has set us back and the sudden change in our circumstances has made us fearful that our dreams may be shattered. As my wife mentioned, we are very uncertain and apprehensive about how our plans and dreams will come true under the current crisis. We don't know how will we manage. But, we do have trust in God that things will come right.

Asim: Do you hope the New Zealand government will open the borders soon?

Asad: We have high hopes that the New Zealand government will open the borders soon, considering that the pandemic is under control in New Zealand. Seeing New Zealand open the border for citizens and permanent residents has made us hopeful that the government will also open the border for students and temporary work visas as the next step. We have high hopes that the border will open for us before the new academic year commences in January and February, and that we will go back to our home. 


\section{References}

\section{Academic}

Aiyar, S. (1995). 'August Anarchy:' The partition massacres in Punjab, 1947. South Asia: Journal of South Asian Studies, 18 (1): 13-36.

Ayres, A. (2005). The Two Punjabs: A Cultural Path of Peace in South Asia? World Policy Journal, 22 (4): 6368.

Bhasin-Malik, K. (2007). In the Making: Identity Formation in South Asia. Gurgaon, India: Three Essays Collective, Pp. 1-137.

Bourdieu, P. (1990). The Logic of Practice. Stanford: Stanford University Press.

Bourdieu, P. (2000). Making the economic habitus: Algerian workers revisited.Ethnography, 1 (1): 17-41.

Brown Pulu, T., Mukhtar, A. and Singh, H. (2019). Sanjha Punjab - United Punjab: Exploring Composite Culture in a New Zealand Punjabi Film Documentary. Sites: A Journal of Social Anthropology and Cultural Studies, 16 (2): 171-187.

Brown Pulu, T., Singh, H. and Sarkaria, G. S. (2018). South Auckland Sikhs and Punjab Issues: Justice, Identity Work and Development. Asian Development Perspectives, 9 (2): 129- 141.

Coffman, E. (2009). Documentary and Collaboration: Placing the Camera in the Community. Journal of Film and Video, 61 (1): 62-78.

Dalrymple, W. (2015). The Great Divide: The violent legacy of Indian Partition. The New Yorker, June 22.

Grewal, J. S. (2008). The Sikhs of Punjab. Cambridge, United Kingdom: Cambridge University Press.

Hall, S. (2006). Encoding/Decoding. In Media and Cultural Studies: Key Works, Revised Edition, edited by M. G. Durham and D. M. Kellner. Oxford, United Kingdom: Blackwell Publishing, Pp. 163-173. Kaur, G. (2019). Maintaining the Panjabi Language and Culture: Auckland's Sikh Gurdwaras and the Home Domain. Unpublished Master of Philosophy 
Thesis, Auckland University of Technology, Auckland, Pp. 1-179.

Khokhlova, L. V. (2014). Majority Language Death. Language Endangerment and Preservation in South Asia, 7: 19-45.

Kirk, G. S. (2016). Uncivilised Language and Aesthetic Exclusion: Language, Power, and Film Production in Pakistan. Unpublished Doctor of Philosophy Dissertation, University of Texas, Austin, 1-261.

O'Sullivan, C. (2007). Multilingualism at the multiplex: a new audience for screen translation? Linguistica Antverpiensia: New Series - Themes in Translation Studies, 6: 81-95.

Parciack, R. (2018). Borderline Nationalism: Restructuring the Wagah-Attari Border 'Retreat Ceremony' and Its Media Representations. South Asia: Journal of South Asian Studies, 41 (4): 744-762.

Power, E. M. (1999). An Introduction to Pierre Bourdieu's Key Theoretical Concepts. Journal for the Study of Food and Society, 3 (1): 48-52.

Rahman, T. (2006). Language policy, multilingualism and language vitality in Pakistan. In Lesser Known Languages of South Asia: Status and Policies, Case Studies and Applications of Information Technology, edited by A. Saxena and L. Borin. Berlin: Mouton de Gruyter, Pp. 73-106.

Roy, A. G. (2007). Digital Culture: Some Beings Who Exchange Information on the Internet. International Journal of Diversity in Organisations, Communities and Nations, 7 (2): $143-151$.

Roy, A. G. (2010). The Punjab Peasant and Digital Culture. In Emerging Digital Spaces in Contemporary Society, edited by P. Kalantzis-Cope and K. GherabMartín. London: Palgrave Macmillan, Pp. 270-271.

Sarroub, L. K. (2002). In-betweenness: Religion and conflicting visions of literacy. Reading Research Quarterly, 37 (2): 130-148. 
Taylor, S., Singh, M. and Booth, D. (2007). Migration, development and inequality: Eastern Punjabi transnationalism. Global Networks, 7 (3): 328-347.

Thompson, M. (1974). The second generation - Punjabi or English? Journal of Ethnic and Migration Studies, 3 (3): 242-248.

Widler, B. (2004). A Survey Among Audiences of Subtitled Films in Viennese Cinemas. Meta, 49 (1): 98101.

\section{Media}

Brody, R. (2015). Jafar Panahi's Remarkable “Taxi.” The New Yorker, October 13.

https://www.newyorker.com/culture/richardbrody/jafar-panahis-remarkable-taxi

Brown Pulu, T. (2020). This is what our future looks like: Punjabi views from New Zealand. The Indian News, September 3.

https://www.indiannews.co.nz/allstories/this-is-whatour-future-looks-like-punjabi-views-from-newzealand

\section{Government}

India Government. (2020). Updates on Covid-19. Website of High Commission of India, Wellington, New Zealand.

New Zealand Government. (2020). FAQs: Repatriation Flights - Information for New Zealanders. Website of New Zealand Foreign Affairs and Trade, Wellington, New Zealand.

\section{Film}

Mukhtar, A. (2020). This is what our future looks like: Punjabi views from New Zealand, a documentary film directed by Asim Mukhtar, 13:21 minutes.

https://www.youtube.com/watch?v=kOdLooR18RQ 